\title{
Pengembangan Perangkat Pembelajaran Berbasis Kit IPA (Fisika) Berorientasi Aktivitas pada Pokok Bahasan Cahaya di SMP
}

\author{
Dian Pramana Putra, Dewi Purwati, Nasharuddin \\ Pendidikan Fisika, Universitas Muhammadiyah Makassar \\ Surat-e: dianpramanaputra06@yahoo.co.id
}

Telah dilakukan penelitian dan pengembangan perangkat pembelajaran fisika berbasis KIT IPA (Fisika) Berorientasi Aktivitas. Subjek uji coba adalah peserta didik kelas VIII SMP Negeri 2 Barombong Kabupaten Gowa berjumlah 32 orang. Prosedur pengembangannya menggunakan model Kemp terdiri dari 9 tahap yaitu menentukan sumber belajar, identifikasi masalah dan tujuan pembelajaran, analisis karakter peserta didik, identifikasi materi pelajaran, menentapkan tujuan pembelajaran khusus, membuat sistematika isi pelajaran, merancang strategi pembelajaran, metodemetode pembelajan, dan mengembangkan instrumen evaluasi. Hasil penelitian menunjukkan bahwa (I) perangkat pembelajaran yang dibuat terdiri dari (RPP), (LKPD), Buku Ajar, Lembar observasi pengamatan keterlaksanaan kegiatan pembelajaran, serta lembar angket respon peserta didik. Bedasarkan penilaian para ahli/pakar, perangkat yang dibuat berada dalam kategori valid, serta adanya respon positif peserta didik yang diperoleh dengan menggunakan angket respon peserta didik terhadap penbelajaran dan perangkat yang digunakan memenuhi kriteria kepraktisan. Perangkat pembelajaran ini memenuhi kriteria efektif karena dapat digunakan untuk meningkatkan aktivitas peserta didik Aktivitas peserta didik dalam pembelajaran berada pada kategori sangat baik, yang menunjukkan perangkat pembelajaran yang digunakan mampu mengaktifkan peserta didik.

Kata kunci: KIT IPA, perangkat pembelajaran, aktivitas

\section{Pendahuluan}

Proses pembelajaran merupakan proses komunikasi pengalihan pengetahuan / ilmu (transfer knowledge) yang terdiri dari berbagai komponen komunikasi yang saling berinteraksi secara terpadu untuk mencapai tujuan pembelajaran. Salah satu komponennya adalah fisika yang merupakan salah satu bagian dari IPA yang diajarkan di SMP yang bertujuan agar siswa mampu menguasai konsepkonsep fisika dan saling keterkaitannya serta mampu menggunakan metode ilmiah yang dilandasi oleh sikap ilmiah untuk menemukan masalah-masalah yang dihadapinya.

Belajar IPA (fisika) merupakan belajar tentang cara memperoleh informasi, cara ilmiah dan teknologi (terapan sains) bekerja dalam wujud pengetahuan prosedural (procedural knowledge), termasuk kebiasaan bekerja ilmiah dengan menerapkan metode dan sikap ilmiah. Belajar IPA (fisika) memfokuskan kegiatan pada penemuan informasi melalui pengalaman yang rentangan kegiatannya meliputi, mengamati, mengukur, mengajukan pertanyaan, mengelompokkan, merencanakan percobaan secara adil, mengendalikan variabel, memecahkan masalah, dan memperjelas pemahaman. Untuk kegiatan seperti ini, siswa perlu disediakan kesempatan dalam bentuk aktivitas berupa pengembangan kreativitas, keterampilan dan pemahaman ini dalam suasana kontekstual yang bermakna. Selain itu, selama kegiatan pembelajaran berlangsung, siswa perlu dibiasakan/dibudayakan beberapa sikap ilmiah seperti sikap jujur dan obyektif terhadap data, sikap ingin tahu, kerja sama, terbuka dan luwes, tekun dan peduli lingkungan. Oleh sebab itu hakekat belajar IPA (fisika) adalah mengembangkan sejumlah kompetensi adaptif yang terkait dengan perubahan kondisi sekarang dan kondisi masa depan. Kompetensi yang dimaksud melalui metode ilmiah yang meliputi kemampuan merencanakan dan melaksanakan percobaan, kemampuan memilih, memilah, dan menata informasi, kemampuan menyimpulkan, dan kemampuan mengkomunikasikan dan menyempurnakan temuan. 
Mengacu pada fungsi dan tujuan mata pelajaran fisika, seyogyanya kegiatan pembelajaran IPA (fisika) itu lebih diarahkan pada kegiatan-kegiatan eksperimen dan atau kegiatan pengamatan lapangan yang dilakukan oleh siswa secara langsung melalui perangkat berupa kit IPA (fisika). Salah satu pendekatan pengajaran yang dilakukan adalah dengan membuat suatu perangkat pembelajaran berbasis KIT IPA yang berorientasi pada aktivitas pada materi tertentu yang ada di sekolah. Dengan menggunakan perangkat pembelajaran berbasis KIT IPA (fisika), diharapkan siswa tidak merasa jenuh di dalam mengikuti suatu mata pelajaran khususnya pada mata pelajaran fisika. Hal ini disebabkan karena siswa akan berperan aktif dalam proses belajar mengajar dan peran guru bukan lagi sebagai pusat informasi tetapi hanya memberikan bimbingan/arahan bagi siswa yang membutuhkan. Penggunaan perangkat pembelajaran berbasis KIT IPA merupakan salah satu alat pembelajaran yang dapat diterapkan dalam pembelajaran fisika guna meningkatkan aktivitas peserta didik. Hal ini akan dapat membangkitkan motivasi serta mendorong anak (siswa) untuk terbiasa bekerja layaknya seorang saintis. Mereka dibiasakan dengan kegiatan pengamatan atau observasi, penemuan dan inkuiri (pendekatan induktif dan deduktif).

Berkaitan dengan itu Munandar (2008 : I0) mengatakan bahwa "kegiatan belajar mengajar IPA hendaknya diberikan melalui menyentuh benda-benda yang nyata”. Dengan demikian mungkin saja diantara para siswa banyak yang sudah mengenal alat-alat yang dipakai mengadakan percobaan oleh gurunya dalam kehidupan sehari-hari. Hal ini menyebabkan pusat perhatian siswa menjadi lebih terpusat pada obyek yang diajarkan dan bukan terpesona. Para siswa akan tertarik bukan pada obyek yang dijelaskan melainkan tertarik pada alat itu sendiri.

Pemahaman terhadap konsep-konsep IPA, terlebih dahulu diawali dengan melihat dan menjalani dengan dasar bahwa segala pikiran berawal dari pengamatan dan pada akhirnya mengerti. Oleh karena itu, kegiatan belajar mengajar IPA hendaknya melalui kegiatan praktikum untuk mengerjakan suatu percobaan diperlukan alat KIT IPA yang mendukung percobaan (Dian,P et.al 2013).

Berdasarkan pendapat di atas, dengan memanfaatkan KIT IPA yang tersedia, para siswa dapat berhadapan secara langsung dengan alat-alat IPA. Hal ini akan memberikan manfaat kepada siswa karena secara langsung dapat mengamati sendiri tentang apa yang disajikan gurunya, bahkan langsung dapat mencobanya.

Penelitian ini dilakukan untuk menjawab masalahmasalah berikut: I) Bagaimanakah bentuk perangkat pembelajaran berbasis KIT IPA (Fisika) yang berorientasi aktivitas pada pokok bahasan cahaya di SMP yang valid, praktis, dan efektif?; 2) Bagaimanakah respon siswa terhadap perangkat pembelajaran fisika berbasis KIT IPA (Fisika) yang berorientasi aktivitas pada pokok bahasan cahaya di SMP ?

\section{Metode Penelitian}

Penelitian ini merupakan penelitian pengembangan dengan menggunakan model Kemp meliputi tahap pendefinisian, perancangan dan pengembangan. Tujuan tahap pendefenisian adalah untuk menetapkan dan mendefinisikan syarat-syarat pembelajaran meliputi analisis identifikasi masalah, peserta didik, tugas, konsep, dan merumuskan indikator. Sedangkan pada tahap perancangan adalah untuk menyiapkan prototipe perangkat pembelajaran meliputi langkah-langkah penyusunan instrumen evaluasi, strategi pembelajaran, pemilihan media dan pelayanan pendukung, evaluasi dan revisi perangkat.

Tahap pengembangan bertujuan menghasilkan perangkat pembelajaran yang telah direvisi sehingga layak digunakan dalam penelitian atau diujicobakan. Kegiatan yang dilakukan pada tahap ini adalah validasi ahli, simulasi, dan uji keterbacaan, serta uji coba terbatas. Hasil kegiatan dalam tahap pengembangan menjadi acuan untuk menilai apakah perangkat yang telah dikembangkan memenuhi kriteria valid, efektif, dan efisien.

Subjek dalam penelitian ini adalah peserta didik kelas VIII.A SMP Negeri 2 Barombong yang terdiri dari 32 orang pada semester genap tahun pelajaran 20I3/20I4. Instrumen yang digunakan dalam penelitian ini adalah lembar validasi perangkat pembelajaran, lembar pengamatan kemampuan guru dalam mengelola pembelajaran, lembar pengamatan keterlaksanan perangkat pembelajaran, dan angket respon peserta didik.

Teknik analisis data yang digunakan yaitu data hasil validasi para ahli untuk masing-masing perangkat pembelajaran dianalisis dengan mempertimbangkan masukan, komentar, dan saran-saran dari validator. Hasil analisis tersebut dijadikan sebagai pedoman untuk merevisi perangkat pembelajaran selanjutnya data tentang respon peserta didik diperoleh dari angket respon peserta didik terhadap perangkat pembelajaran.

\section{Hasil dan Pembahasan}

Pada tahap penetapan identifikasi masalah pembelajaran, Penelitian ini dilaksanakan di SMP Negeri 2 Barombong pada peserta didik kelas VIII.A dengan pokok bahasan Cahaya dengan objek penelitian yang terdiri dari 32 peserta didik.

Analisis peserta didik dilakukan untuk mengetahui karakteristik peserta didik yang sesuai dengan rancangan 
dan pengembangan bahan pembelajaran. Berdasarkan hasil wawancara peneliti dengan pihak sekolah, yaitu guru bidang studi fisika, maka diperoleh beberapa penjelasan tentang karakteristik peserta didik, rata-rata usia peserta didik yang menjadi subjek penelitian adalah I3 tahun. Menurut teori Piaget (dalam Trianto, II3: 2008), bahwa anak dalam kelompok usia seperti itu berada dalam tahap operasi formal atau mereka telah mampu berpikir abstrak. Jadi, pada tahap ini para peserta didik sudah mampu menyelesaikan masalah dengan cara yang lebih baik dan kompleks daripada anak yang masih berada dalam tahap operasi kongkrit. Pada tahap ini peserta didik sudah mampu berpikir secara logis tanpa kehadiran benda-benda konkrit. Peserta didik rata-rata berumur I3 tahun sehingga kemampuan berpikir logik dan bernalar abstrak dapat berkembang. Namun, di usia tersebut terkadang ada peserta didik memerlukan benda-benda konkrit dalam pembelajaran fisika, termaksuk hal-hal yang terkait dengan pengalaman keseharian mereka.

Hal ini disebabkan karena adanya perbedaan tingkat intelektual anak. Piaget mengemukakan bahwa anak yang tahap berpikirnya masih berada pada taraf operasional konkrit tidak dapat memahami operasi (logik) dalam konsep IPA tanpa dibantu benda-benda konkrit. Berdasarkan pendapat ini, nampak bahwa kehadiran KIT IPA sangat tepat untuk menanamkan konsep-konsep IPA secara nyata.

Pada perkembangannya, siswa selalu menafsirkan apa saja yang mereka lihat, rasakan atau sesuai dengan apa yang mereka cerna dalam pikirannya. Kematangan berpikirnya pun selalu berubah sesuai dengan tambahan pengalaman serta interpretasinya terhadap pengalaman yang baru itu. Anak belum dapat berpikir abstrak, kemampuannya untuk berpikir abstrak harus selalu didahului oleh pengalaman konkrit.

Analisis tugas meliputi analisis isi pelajaran, analisis konsep, dan analisis prosedural. Analisis tugas dilakukan untuk mengedintifikasi tahap-tahap dalam penggunaan KIT IPA dengan pokok cahaya. Sesuai standar isi dari Badan Standar Nasional Pendidikan (BSNP) untuk jenjang pendidikan Sekolah Menengah Pertama (SMP) kelas VIII seperti tercantum dalam silabus bahwa pengetahuan yang harus dimiliki peserta didik dalam pokok bahasan Cahaya sesuai dengan Standar kompetensi yakni memahami konsep dan penerapan optika dalam produk teknologi sehari-hari Puskur (2002).

Tahap perancangan, penyusunan instrumen evaluasi, strategi pembelajaran, pemilihan dan penggunaan media yang sesuai dengan tujuan, konsep, kondisi lingkungan dan fasilitas serta waktu yang disediakan untuk kebutuhan pembelajaran. Validasi dilakukan oleh ahli media dan ahli materi untuk mengetahui kevalidan perangkat pembelajaran. Berdasarkan penilaian perangkat pembelajaran oleh validator, diperoleh hasil valid untuk setiap pernyataan yang diberikan. Hal ini mengindikasikan bahwa RPP, LKPD, Buku Ajar,dan lembar instrumen peserta didik umumnya berada pada kategori valid/layak dan dapat digunakan.

Hasil pengamatan keterlaksanaan perangkat pembelajaran berbasis KIT IPA dapat digambarkan seperti diagram berikut:

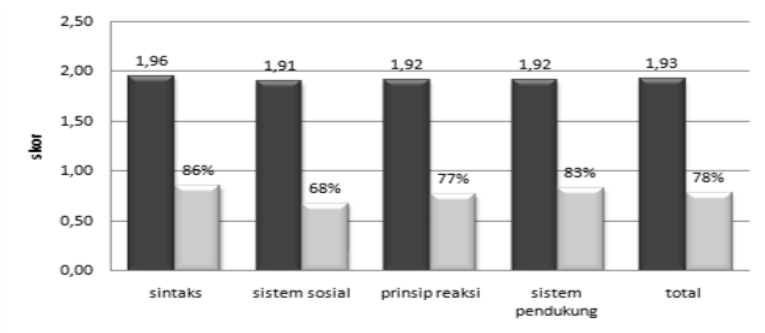

Gambar I. Diagram Hasil pengamatan keterlaksanaan perangkat pembelajaran

Pembelajaran adalah untuk melihat sejauh mana tingkat keterlaksanaan perangkat dalam proses pembelajaran. Berdasarkan hasil analisis data observasi pengamat tentang keterlaksanaan perangkat pembelajaran dapat dirangkum seperti pada tabel berikut:

Tabel I. keterlaksanaan perangkat pembelajaran

\begin{tabular}{clll}
\hline No. & Aspek yang dinilai & $\bar{x}$ & Ket. \\
\hline I. & Tahapan/fase & I,96 & Terlaksana seluruhnya \\
2. & Sistem sosial & I,9I & Terlaksana seluruhnya \\
3. & Prinsip reaksi & I,92 & Terlaksana seluruhnya \\
4. & Sistem Pendukung & I,92 & Terlaksana seluruhnya \\
\hline & Rata-rata total & I,93 & Terlaksana seluruhnya \\
\hline
\end{tabular}

Data pengamatan keterlaksanaan perangkat pembelajaran diperoleh melalui observasi yang dilakukan oleh dua orang pengamat. Yang terlihat bahwa keterlaksanaan perangkat pembelajaran berada pada rata-rata $\mathrm{M}=\mathrm{I}, 93$ yang menunjukkan bahwa semua komponen yang diamati pada pelaksanaan perangkat pembelajaran berbasis KIT IPA terlaksana seluruhnya dengan koefisien reliabilitas 0,784 atau persen agrement $78,4 \%$. 


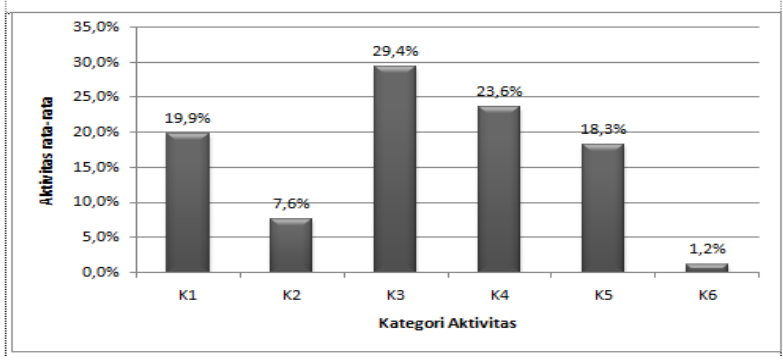

Gambar 2. Diagram Hasil Persentase dari kategori aktivitas

Keterangan:

$\mathrm{KI}=$ Kategori mendengarkan/memerhatikan informasi dan penjelasan guru

$\mathrm{K} 2$ = Kategori merencanakan Tugas/Identifikasi Topik

$\mathrm{K} 3=$ Kategori melaksanakan investigasi dengan teman kelompok

K4 = Kategori menyiapkan laporan akhir/Menyelesaikan LKPD

K5 = Kategori mempresentasekan, menanggapi dan memerhatikan hasil kerja kelompok

$\mathrm{K} 6=$ Kategori perilaku yang tidak relevan

Persentase dari kategori aktivitas menunjukkan persentase rata-rata jumlah kesuluruhan aktivitas untuk seluruh peserta didik pada setiap indikator. Dari diagram diatas juga dapat dilihat bahwa setiap kategori berada pada rentang baik yang berarti aktivitas peserta didik berada pada kategori ideal.

Berdasarkan data hasil respon peserta didik diperoleh bahwa pada umumnya merasa senang terhadap komponen pembelajaran berupa buku peserta didik, lembar kegiatan peserta didik, proses pembelajaran, dan bahasa. Sebanyak $85 \%$ peserta didik memberikan pernyataan positif terhadap buku peserta didik (BPD), 84\% peserta didik memberikan pernyataan positif terhadap lembar kegiatan peserta didik (LKPD), $85 \%$ peserta didik memberikan pernyataan positif terhadap pelaksanaan pembelajaran kooperatif tipe investigasi kelompok dan $88 \%$ peserta didik memberikan pernyataan positif terhadap bahasa yang digunakan pada perangkat pembelajaran dan hal itu dapat disimpulkan bahwa respon peserta didik terhadap perangkat pembelajaran berbasis KIT IPA dan pelaksanaan kegiatan pembelajaran umumnya memberikan respon positif. Dengan demikian hasil respon peserta didik terhadap perangkat pembelajaran dan pelaksanaan kegiatan pembelajaran dapat digambarkan seperti diagram berikut.

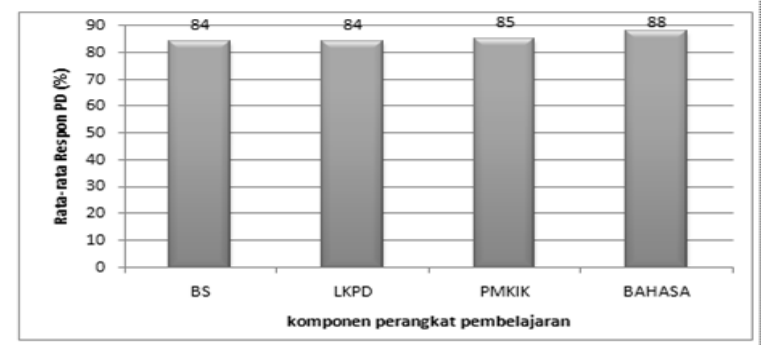

Gambar 3. Diagram Hasil respon peserta didik terhadap perangkat pembelajaran

\section{Kesimpulan}

Berdasarkan hasil penelitian yang telah dilakukan pada peserta didik kelas VIII A SMP Negeri 2 Barombong, dapat disimpulan: a) Profil perangkat pembelajaran yang dihasilkan dalam penelitian ini meliputi: (I) Rencana Pelaksanaan Pembelajaran, (2) Buku Peserta didik, (3) Lembar Kegiatan Peserta didik, (4) Lembar respon siswa berdasarkan hasil validasi menunjukkan bahwa perangkat pembelajaran berbasis KIT IPA berorientasi aktivitas memenuhi kriteria valid, praktis, dan efektif; b) Respon peserta didik terhadap perangkat pembelajaran berbasis KIT IPA berorientasi aktivitas umumnya memberikan respon positif.

\section{Kepustakaan}

Dian, P., Nurlina., and Rahmini., Peranan penggunaan KIT IPA (Fisika) terhadap hasil belajar fisika siswa MA Muallimin Muhammadiyah Makassar, Jurnal Pendidikan Fisika Unismuh (JPF), vol. 2 no.2 2013, pp 26-30.

Fajriani., and Mursalim., Penerapan KIT IPA berbasis lingkungan terhadap kreativitas pada siswa SMP Negeri ISuli Kab.Luwu terhadap hasil belajar fisika siswa MA Muallimin Muhammadiyah Makassar, Jurnal Pendidikan Fisika (JPF), vol. I no.I 2012, pp 37-4I.

Munandar. 2008. Pembelajarn IPA Di Sekolah Menengah Pertama Bandung: Alfabeta.

Trianto. 2007. Model Pembelajaran Terpadu dalam Teori dan Praktek. Jakarta: Prestasi Pustaka

Diqfaini, Ana 2007. Pengaruh penggunaan peralatan KIT IPA dalam Pembelajarn IPA Terhadap prestasi belajar IPA siswa SMP Negeri 26 Makassar

Puskur. 2002. Kurikulum Bebasis Kompetensi : Kegiatan Belajar mengajar: Jakarta

Nurdin 2007. Model Pembelajaran Matematika Yang Menumbuhkan Kemampuan metakognitif untuk Menguasai Bahan Ajar. Ringkasan Disertasi. Surabaya : PPs UNESA 